\title{
粒子アセンブルを目指した技術開発
}

\section{Development of New Handling Techniques for Particle Assemblage}

\author{
小林 幹 彦*, 檀 武 弘*, 不動寺 浩*, 新谷 紀 雄 ${ }^{*}$ \\ Mikihiko KOBAYASHI, Takehiro DAN, Hiroshi FUDOUZI, Norio SHINYA
}

Key Words : Particle Assemblage, Ordered Mixture, Particle Arrangement, Electrification

\section{1.はじめに}

近年，急速な発展を遂げたエレクトロニクス技術の 根幹をなす思想は「集積化」および「高機能化」の 2 つのキーワードで表現できるであろう。IC（集積回 路）を例にとると， 1 個のICの中に総計が 1 億個にも 及ふ整流器, 増幅器, 抵抗, コンデンサー等の素子が 集積化されて，IC 自身が 1 つの装置に相当する高度 な機能を持っている。

この思想を材料分野に移植し，ICにおけるようにい ろいろな機能を持つ素材を集積化し，素材の機能をう まく連動させる技術を開発できたならば，材料自身に 機械部品や電子部品, さらには装置に相当するような 高度な機能を発現させることも不可能ではないであろ $j^{1,2)}$ 。

本記事の「粒子アセンブルを目指した技術開発」 は，このような考えに基づいて，より高機能な材料を 創製する手段として提案するものである。

ICにおける個々の素子に相当するものとして，粉 体粒子を考えている。いろいろな機能を持つ素材の粉 体化は比較的容易であり，ある特定の機能を発現する 素材を粒子として入手することは，ほとんどの場合， 可能である。また, リソグラフィ技術に相当する技術 は，粒子アセンブル技術である。

\footnotetext{
1997 年 12 月 2 日受付

* 金属材料技術研究所 第 5 研究グルーフ

（テ305-0047つくば市千現 1-2-1） TEL. 0298-59-2425

National Research Institute for Metals

(1-2-1, Sengen, Tsukuba-shi, 305-0047)
}

〈著者紹介〉

小林幹彦

昭和 56 年京都大学工学研究科修了, 科学技術庁金属材料技術研究所 入所，現在同所第 5 研究グループ第 1 サブグループリーダー、

工学博士。

専門: 液相プロセス，現在液相法を適用した粒子配列技術とその応 用について研究している

Vol. 35 No. 2 (1998)
基本的な粒子アセンブル技術として，粒子への機能 付与や多機能化技術，およびそれらの粒子を精密に集 積しデバイスや材料とする技術がまず考えられる。そ こで，われわれは，粒子への機能付与・多機能化のた めに，親粒子に子粒子が付着したオーダードミクスチ ヤ一の作製技術3.4) を，また粒子の集積化のために ビームを利用した粒子の配列技術 ${ }^{5)}$ を，それぞれ開発 している。以下でその成果を順に述べる。

\section{2. 粒子への機能付与, 多機能化に関する研究}

\section{1 オーダードミクスチャー作製技術の概要}

粒子アセンブルでは, ある場合には親粒子 1 個と子 粒子 5 個からなるオーダードミクスチャー, 別の場合 には親粒子 1 個に対して子粒子 10 個のオーダードミ クスチャーというように，粒子の混合比を自由に制御 できることが望ましい。このようなことが可能な方法 として，親粒子と子粒子をそれぞれ逆極性に帯電さ せ, 両者を静電気力で複合化させようとする強制帯電

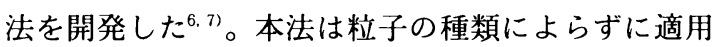
可能なこと, 帯電量を制御することにより混合比を調 節できること，さらに子粒子同士が同極反発のため に，親粒子に均一に分散して付着するというメリット がある。

2 種類の粒子の単なる混合でも, 両粒子の接触電位 差が大きい場合には，それぞれ逆極性の帯電が生じ,

静電気力によるオーダードミクスチャーが形成され る ${ }^{8)}$ 。しかし，この場合には粒子の組合せに大きな制 約があり, 普遍的なオーダードミクスチャ一製造法と は言い難い。

オーダードミクスチャー作製のための強制帯電処理 装置の模式図を図 1 に示す。試料を帯電させる帯電室 は, 一端封じの真鍮製円筒容器で，それぞれ親粒子お よび子粒子の帯電のために 2 室ある。それぞれに試料 


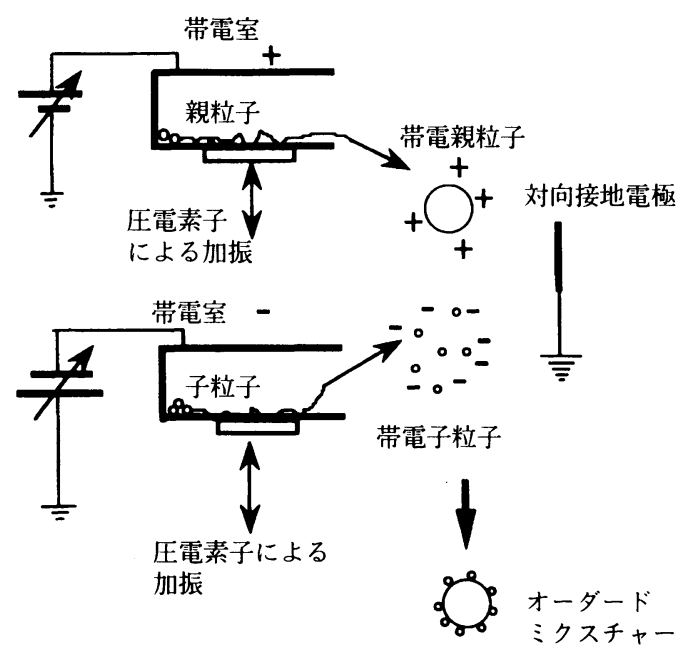

図 1 粒子強制帯電装置によるオーダードミクスチャー 作製の模式図

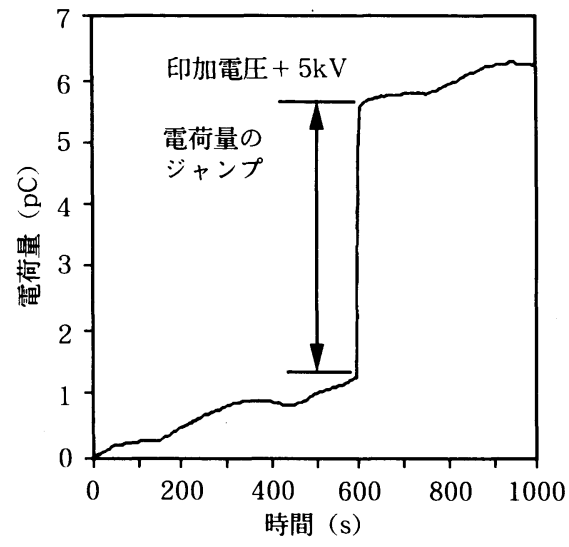

図2 ファラデーケージ中の電荷量の変化の例

粒子を装入し, 開口部を蓋で閉じた後, 帯電室に正及 び負の直流高電圧を印加する。この際，帯電室に圧電 素子で振動を加え, 試料粉末の転動を促した。所定時 間後に，2つの帯電室の蓋を同時に取ると, 帯電室内 の試料粉末は同極に帯電しているので反発しあって, 開口部より飛び出す。その際に親粒子及び子粒子が同 一空間を通るように帯電室を配置すると，その領域内 を通過する時に静電引力でオーダードミクスチャーが 生成する。

\section{2 粒子の帯電量}

図 1 に示した装置で実際に粒子を帯電させることが できるのか，また混合比を決定する最も重要なパラ メータである粒子の帯電量を制御できるかを調べるた めに, 次のようにして 1 個当りの帯電量を求めた。

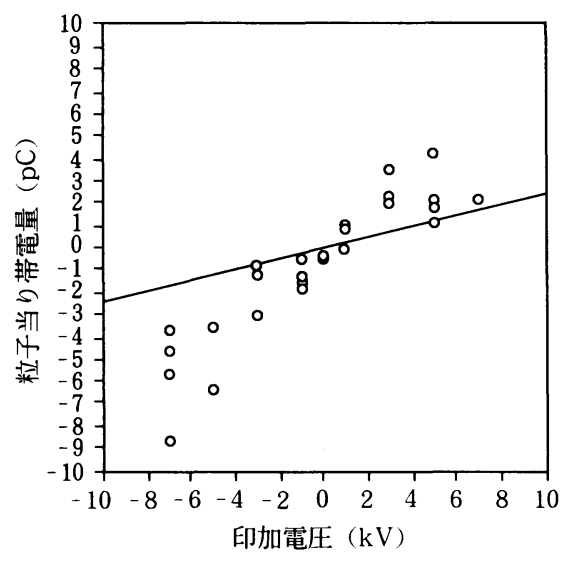

図3粒子帯電量と印加電圧の関係 実線 : 誘導荷電による導体粒子の最大 帯電量（式(1)および本文参照）

図 1 の装置で 1 つの帯電室だけを使って粒子を帯電 させ, 飛び出した粒子が落下する位置にファラデー ケージを置き，ファラデーケージ中の電荷量をモニ ターする。例えば直径 $400 \mu \mathrm{m}$ の金粒子を使うと, フ アラデーケージ中の電荷量は, 図 2 のように変化す る。測定電荷量は周冊の雑音によりほぼ一定の速度で 增加している。しかし, 測定中に粒子が飛来すると電 荷量が大きくジャンプする。これは飛来した粒子が帯 電していたためで，ジャンプ幅は粒子の帯電電荷に相 当すると考えられる。ジャンプした電荷量の総和を, 測定終了後に数えたファラデーケージ中の粒子数で割 り, 粒子 1 個当りの平均帯電量を計算した。

帯電室への印加電圧を変えて測定を行った結果を, 図3に白丸で示した。ぱらつきは大きいが，全体とし ては正の相関が涊められ，印加電圧が高くなるほど帯 電量が大きくなる。従って, 印加電圧で粒子の帯電量 が制御できるといえる。

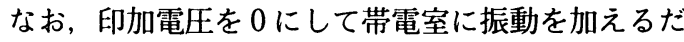
けでも，粒子はやや負に帯電する。これは粒子（Au） と帯電室 (真鍮) との接触電位差による帯電と考える と, 仕事関数の大きい粒子が負に帯電する筈であり, 実験結果と一致する。

誘導荷電による導体粒子の最大帯電量 $q(\mathrm{C})$ と印加 電界強度 $E(\mathrm{~V} / \mathrm{m})$ の関係は, 式（1）で表される ${ }^{9)}$ 。

$$
q=1.65 \times 4 \pi \varepsilon_{0} r^{2} E
$$

ここで $\varepsilon_{0}$ は真空の誘電率 $\left(8.8541 \times 10^{-12} \mathrm{~F} / \mathrm{m}\right), r$ は粒子の半径 $(\mathrm{m})$ である。

帯電室と対向接地電極がそれぞれ平行平板電極とし た場合の, $q$ と印加電压の関係を上式より求め, 結果 


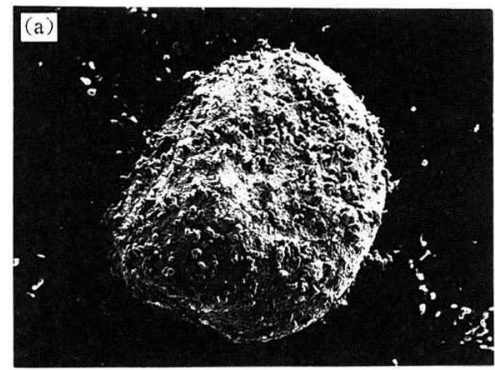

$200 \mu \mathrm{m}$

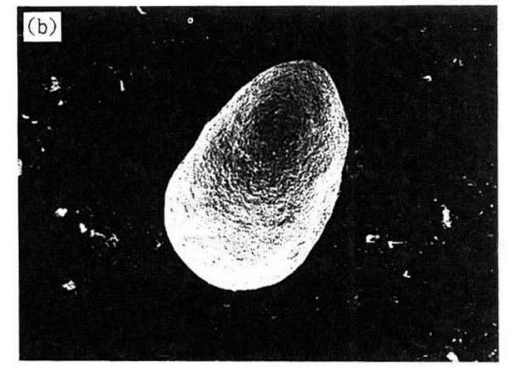

$200 \mu \mathrm{m}$

図 4 半導体化 $\mathrm{BaTiO}_{3}$ 粒子の走査電子顕微鏡写真

(a) 強制带電処理によるIn との複合化後, (b) 強制带電処理前

を図 3 に実線で示した。図 3 の結果は, 実線の最大帯 電量をはるかに越えて粒子が帯電することを意味す る。これは帯電室出口で電界集中がおこり, 平行平板 の場合よりも高い電界が粒子に印加されたためであ る。電界解析を行うと, 最大で平行平板とした場合の 10 倍以上の電界となり, しかも帯電室の出口付近 で, 電界強度が大きく変化していることがわかった。 従って, 図 3 のデータがばらついているのは, 粒子が 带電室の出口のどの部分を通るかによって粒子に印加 される最大電界強度が变わり, 従って帯電量も変わる ためと考えられる。

半導体化 $\mathrm{BaTiO}_{3}$ 粒子や, 直径 $400 \mu \mathrm{m}$ のジルニア 粒子についても同様の結果が得られており, 本帯電装 置によりさまざまな粒子に対して, 極性と帯電量の制 御が可能と思われる。

\section{3 オーダードミクスチャーの作製}

直径約 $400 \mu \mathrm{m}$ の半導体化 $\mathrm{BaTiO}_{3}$ 粒子を親粒子, 直 径約 $20 \mu \mathrm{m}$ のIn 粒子を子粒子にして，作製したオー ダードミクスチャーの写真を図 4 (a) に示す。ま た, 図 4 (b) は親粒子の半導体化 $\mathrm{BaTiO}_{3}$ 粒子の写真 である。図4（a），(b) から，オーダードミクスチ ヤーではIn粒子が多数表面に付着していることがわ かるが，さらに表面を拡大すると，In粒子は同極反 発により分散して付着していることが確認された。

In 粒子は $\mathrm{BaTiO}_{3}$ 粒子表面に, 静電気力で付着して オーダードミクスチャーとなるが, 時間と共に電荷は 中和して失われていく。従って, 最終的には通常の粒 子間の付着と同様にファンデルワールスカで付着する ことになる。ただしこの場合, Inの粒子径が $20 \mu \mathrm{m}$ 上 大きく，また金属で比重が大きいこともあり，取扱中 の衝撃で一部の In 粒子は離れてしまった。今回作製 した粒子は静かに取り扱うことで, 複合化状態は保た れるが, 熱処理や接着剂等による付着力の強化は今後

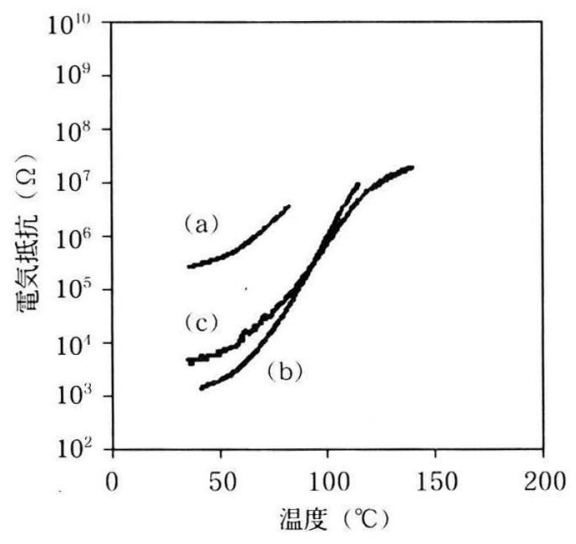

図5 半導体化 $\mathrm{BaTiO}_{3}$ の抵抗の温度依存性

（a）粒子充填層，（b）焼結体ディスク,

(c) Inとのオーダードミクスチャーの充填層

の検討課題である。

2. 4 オーダードミクスチャー作製技術の応用

2. 4. 1 PTC 粒子集合体の低抵抗化 ${ }^{10.11}$

半導体化 $\mathrm{BaTiO}_{3}$ 粒子充填層の抵抗の温度依存性, およびその焼結体ディスクの抵抗の温度依存性を, 図5にそれぞれ（a），(b) で示した。粒子充填層の 場合は, 透明石英管に詰めて, 棒状の電極で両端から 一定荷重を掛けながら測定を行っている。ディスクは 充填層を作ったのと同じ組成の粒子をプレスして成形 した後, 熱処理して作製している。それぞれ試料と電 極の間にはIn箔を入れて測定を行った。なお，ディ スク試料は，充填層と同じ形状に成形したので，充填 層との電気抵抗の比較においては, 測定值をそのまま 使っている。

図に見られるように, 半導体化 $\mathrm{BaTiO}_{3}$ はある温度 範囲で, 温度の上昇と共に電気抵抗が急激に上昇す る, いわゆる PTC 特性を持つ。この特性は結晶粒界 
の性質に起因しており, 多結晶の粒子, あるいはその 充填層もPTC の機能を発現する。

図 5 では粒子充填層は, 確かにPTC 特性を示し, 抵抗変化の割合は変わらない。しかし, 抵抗の絶対値 は充填層の方が 2 桁以上高くなる。これは充填層の場 合, 粒子接触面での抵抗が大きいためと考えられる。

そこで2. 3 項で作製した半導体化 $\mathrm{BaTiO}_{3}$ と In の オーダードミクスチャーを用いることとした。この オーダードミクスチャーで充填層を作ると, 半導体化 $\mathrm{BaTiO}_{3}$ 粒子同士は必ず Inを介して接触する筈であ る。Inはセラミクスとの接合界面でショットキーバ リアを形成せずオーミックな抵抗を示すと言われてお り, 界面での抵抗を下げると考えられる。オーダード ミクスチャー充填層の抵抗の温度依存性を測定した結 果は, 図 5 中に実線 (c) で示されるように, PTC特 性を損なわずに抵抗值を焼結体の抵抗值に近づけるこ とができた。

Inが互いに接触してローカルな電導性のネット ワークを作ると, ネットワーク内部の半導体化 $\mathrm{BaTiO}_{3}$ 粒子の寄与がなくなり, 全体として PTC特性 が少化する。ここで述べた強制帯電を利用した方法で は, 先にも述べたようにIn粒子が反発し合い, 分散 して付着するのでInがネットワークを作ることは考 えられない。

一般にセラミクスは高温で粉末を焼結して成形体を 作る。しかし, 機械的強度を必要としない場合には, 粒子を適当な溶媒に分散させ, 簡単にPTC特性を示 す塗・被膜を作るといったことが考えられる。その際 に, オーダードミクスチャーを用いると, 粒子間の接 触界面の悪影響を避けることができる。

塗・被膜の比抵抗が焼結体の比抵抗と同じ程度まで 下がると，成形が自在なヒーターとして用いるような 応用が考えられる。また，成形時の熱処理が不要であ ることから，デバイスとの集積を行えるといった利点 もあり，さまざまな応用が開けると期待される。

\section{4. 2 PTC特性と NTC 特性の複合化, 12)}

電気抵抗の温度依存性がV字型となるような材料 は, 電源投入時の突入電流の抑制, 回路異常時の過 電流防止，スイッチング機能等広い範囲に応用が期 待される。V 型の電気抵抗の温度特性は, PTC特性 と NTC 特性を加算したものと考えられる。そこで, PTC 粒子と NTC 粒子の複合化により上記の特性を得 ることを試みた。

PTC 粒子と NTC 粒子の単なる複合化では，接触面 での抵抗值が高くなることは明かである。これを避け

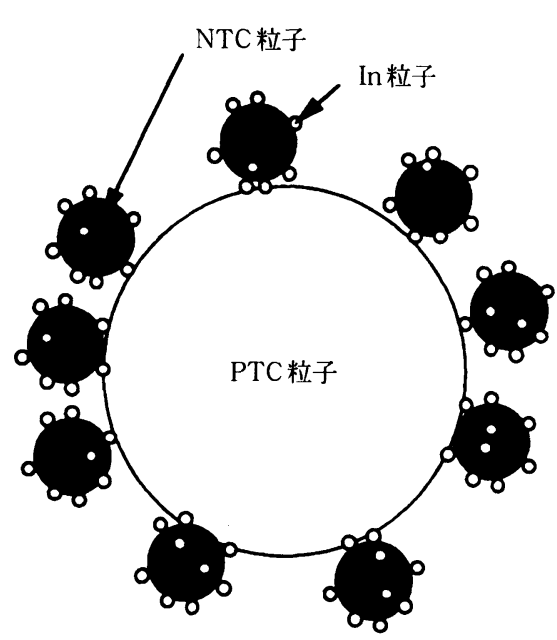

図6 PTC 粒子, NTC粒子及び In 粒子の 階層的オーダードミクスチャー

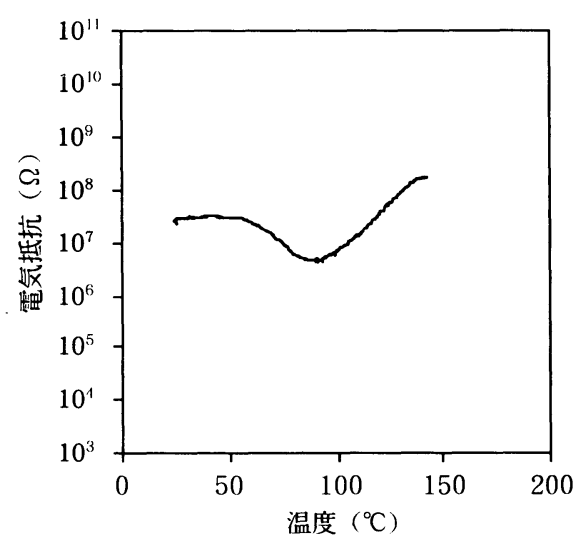

図7 PTC-NTC-Inの階層的オーダードミクスチャー 充填層の抵抗の温度依存性

るためには，PTC粒子と NTC粒子の間に，必ずIn粒 子を挟むようにする工夫が必要である。そこで先ず, NTC 粒子とIn 粒子のオーダードミクスチャーを作製 し,さらにこのオーダードミクスチャーをPTC 粒子 と複合化させた。すなわち親粒子をPTC 粒子とする と, 親粒子の周囲に, 孫粒子の Inを周囲に配置した 子粒子の NTC 粒子が配置されるという，階層的な オーダードミクスチャーを作製した ${ }^{13)}$ 。その概念図 を図6に示した。

このオーダードミクスチャー充填層の抵抗の温度依 存性を図 7 に示す。図 7 は, 電気抵抗が V 型の温度依 存性を示し，2つの粒子の機能を加算できることがわ かった。ただし，PTCの焼結体ディスクと NTC の焼 結体ディスクを重ねて測定した結果と比較すると, V 
型の極小部分の抵抗値がかなり高くなる。これは NTC-InのオーダードミクスチャーとPTC 粒子との 強制帯電処理の際, NTC-Inのオーダードミクスチ ヤ一からのIn粒子の脱落が観察されており, PTC 粒 子と NTC 粒子との間に介在すべきIn粒子がかなり脱 落しためと考えられる。

図 6 の階層的オーダードミクスチャーは, PTC特 性と NTC 特性を加算した多機能粒子といえる。これ らの例で示されるように, 強制帯電処理によるオー ダードミクスチャー作製技術は, 粒子の組合せに制約 を受けることのない, 粒子への機能付与および多機能 化の有力な手法である。

\section{3.ビームを利用した粒子の集積化に関する研究}

\section{1 粒子配列技術の概要}

前章で述べたように粒子を複合化すると，粒子への 機能の付与や多機能化が可能となり, さまざまな応用 が期待される。さらに進んで, 多種の粒子を集積し, それらの機能を連動させた, 高度な機能の材料やデバ イスを創製するには, 粒子を精密にかつ大規模に集積 することが求められる。すなわち, 特定種類の粒子を 特定の位置に配置する精密さと, ある程度の大きさに なるまで集積させる効率性・量産性が必要となる。

そこで, われわれは電子ビーム, イオンビームを利 用して粒子を配列する位置を決め, 静電気力により粒 子を帯電位置に誘導する方法を開発している ${ }^{14-199}$ 。 ミクロンオーダーの粒子サイズでは, 静電気力はファ ンデルワールスカや重力に匹敵する大きさであり，ま た力の作用範用が広いので, 粒子の誘導は充分に可能 である。

電子ビームやイオンビームによるパターニングは, 微細加工技術と関連して発展しており, 微細なパター ンの粒子配列にも適用可能と考えられる。

電子ビームやイオンビームを用いた粒子の集積によ る材料創製を，図 8 に模式的に示す。基板上を電子 ビームまたはイオンビームで, あるパターンに沿って 走査すると，基板に負または正の帯電パターンが作ら れる(描画)。粒子をパターンの近傍に持ってくる と, 粒子は静電気力でパターンに引き寄せられ, パ ターン上に吸着する（配列）。吸着した粒子はなんら かの方法で動かないようにし (固定), 再び描画, 配 列を繰り返す。その際, 近傍に持ってくる粒子の種類 を変えてやると, 複数種類の粒子で配列体を作ること ができ，さらに積層して立体構造を作ることができ る。

Vol. 35 No. 2 (1998)

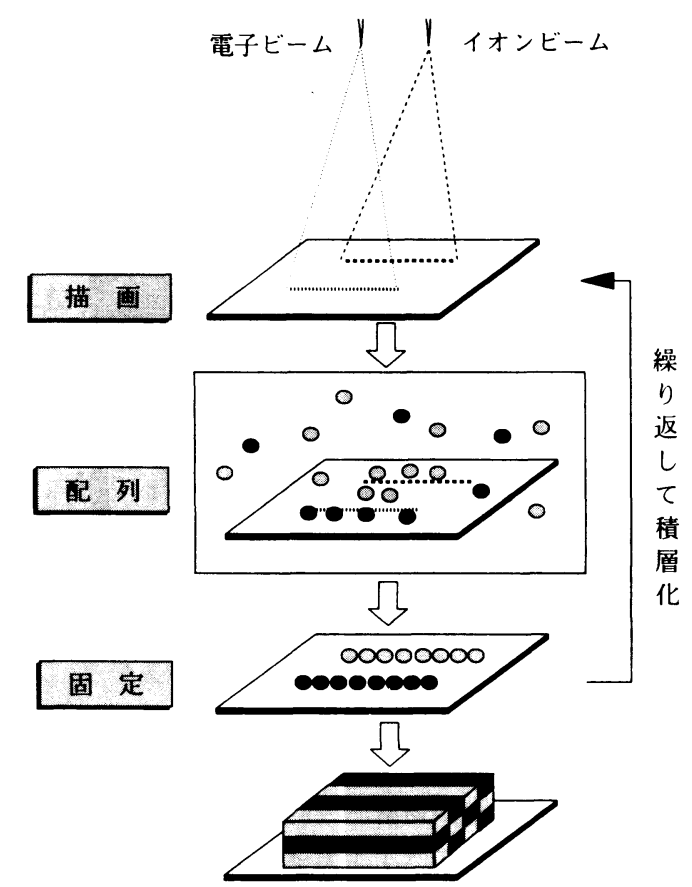

図8 ビームを用いた粒子の集積による材料の創製

ビームによる粒子配列では描画, 配列, 固定の $3 つ$ の要素技術が必要であり, それぞれ開発を行ってい る。ここではモデル粒子として直径 $5 \mu \mathrm{m}$ の真球 $\mathrm{SiO}_{2}$ を, 平滑で高絶縁性の多結晶 $\mathrm{CaTiO}_{3}$ 基板に並べた結 果について, 描画, 配列, 固定及び積層の順に述へ る。なお，粒子としては $\mathrm{SiO}_{2}$ のような絶縁体だけで はなく, 金属粒子や半導体粒子も配列可能であること は確認している。

\section{2 粒子配列結果}

\section{2.1 描 画 ${ }^{14,15,16)}$}

帯電像形成のために, 電子ビームおよびガリウムイ オンビーム両方が使えるデュアルビーム装置を試作し た。図 9 に示すように電子ビーム用鏡筒とガリウムイ オンビーム用鏡筒を備えており, コンピュータ制御に より, どちらのビームででも, 任意の帯電パターンを 作ることができる。

図10（a），（b）はそれぞれ電子ビームおよびイオ ンビームで描画した結果である。電位コントラスト法 では，正に帯電した領域は黒く，負に帯電した領域は 白く見える。図よりわかるように, 電子ビーム描画で は描画領域は負に帯電すると推定される。一方, イオ ンビーム描画の場合は黒いパターンとなり, 正の帯電 パターンが形成されるようである。これらは表面電位 計による直接測定でも裏付けられた。帯電パターンの 


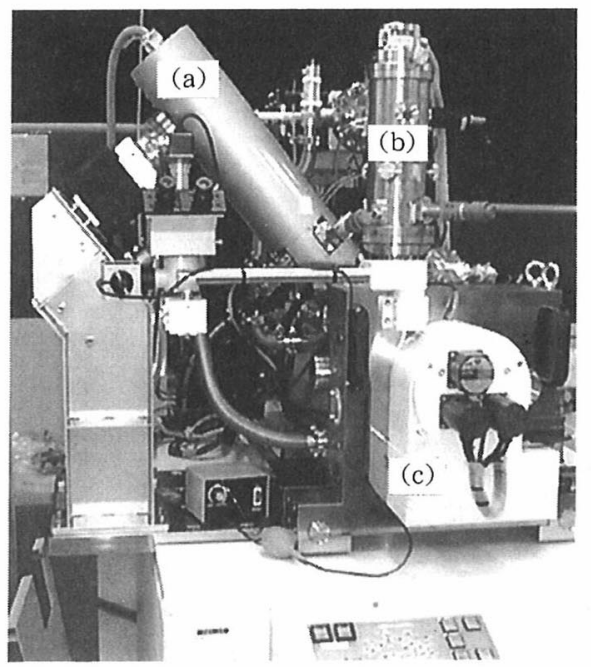

図9帯電描画のためのデュアルビーム装置

（a）電子ビーム用鏡筒，（b）イオンビーム用鏡筒,

(c) 試料室
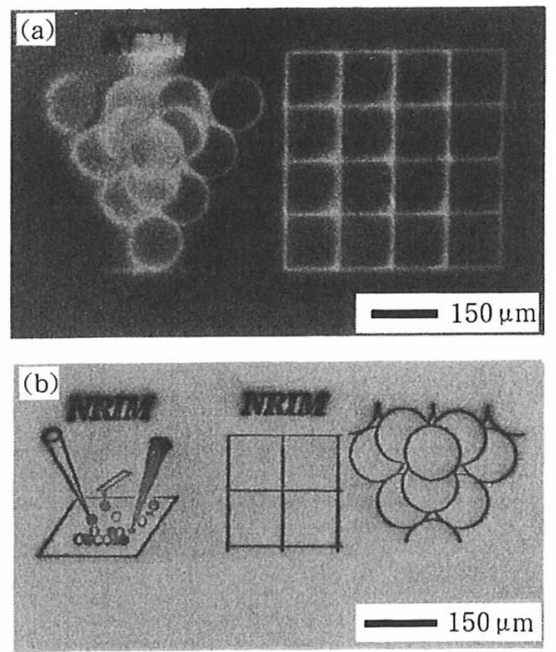

図 10 電位コントラスト法で観察した帯電描画像 （a）電子ビーム描画，（b）イオンビーム描画

正負を制御できるので，コロナ放電や摩擦を利用して 帯電させた粒子を配列する場合には，粒子の帯電電荷 の正負に応じた带電パターンを選ぶことができる。

電子ビームおよびイオンビームのスポット径は $1 \mu \mathrm{m}$ 以下であるが，基板に照射した際の散乱および 帯電後の電荷の拡散により, 带電領域はスポット径以 上にまで広がる。帯電領域の広がりは主としてドーズ 量により決まり, ドーズ量が多いほど大きくなる。例 えば, 電子ビーム描画を行う場合, 後述の配列結果を

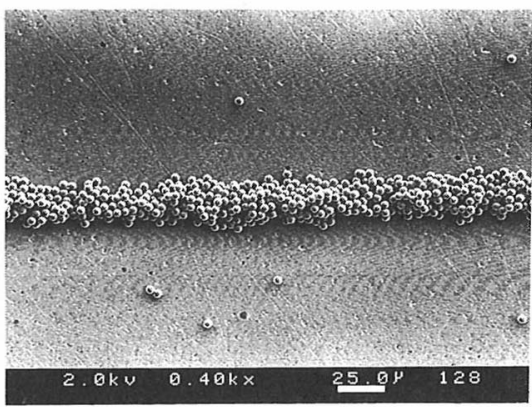

図11 線状に配列した粒子像

考慮にいれると，最適な加速電圧は $10 〜 20 \mathrm{kV}$, 最適 ドーズ量は $1 \mathrm{pC} / \mu \mathrm{m}^{2}$ 以下と思われる。イオンの方が 電子より重く動き難いので，一般にイオンビーム描画 の方が電子ビーム描画の場合よりも帯電領域の広がり が少なく, 最適条件での帯電幅はイオンビームの場合 約 $7 \mu \mathrm{m}$ ，電子ビームの場合約 $20 \mu \mathrm{m}$ であった。

基板は高絶縁性であるが, それでも帯電電荷は時間 と共に拡散し, さらには消失していく。しかし, 描画 後にすぐ後述の配列処理と同じ操作 (液に浸漬) をし てから帯電像を観察すると, 線幅がやや広がっている が帯電像はそのまま残っていることがわかった。ま た, 表面電位計による測定でも配列操作の時間（最大 数分）程度では, 電荷は殆ど減衰しないことが示され た。従って, 本プロセスにおいては帯電像の時間経過 による劣化は問題にならないと思われる。

\section{2.2 配 列 ${ }^{17.18)}$}

帯電パターンの近傍に粒子を持ってくるために，描 画した基板を粒子分散液に浸漬した。帯電を保持する ために，溶媒は不活性で非極性のものでなければなら ず，フッ素系の溶媒を用いている。

予備実験で最適な粒子分散濃度および浸漬時間を決 めた。分散濃度が $10^{5} / \mathrm{ml}$ 以下ではパターン上に粒子 は殆ど付着せず, $10^{7} / \mathrm{m} l$ 以上では，ノイズ粒子と呼 ばれるパターン以外の部分に付着する粒子が多数現れ る。また, 付着粒子数は浸漬時間に対してほぼ直線的 に増加するが, 特に浸漬初期の数秒間は急増し, 以後 は漱增する。

図11は, 線状の帯電パターンを描いた基板を, 分 散濃度 $3 \times 10^{6} / \mathrm{ml}$ の液に 30 秒間浸漬して得られた粒 子像である。粒子が 10 列分程度に広がり，また重な りあって直線上に配列していることがわかる。浸漬時 間を短くすると, 線幅は狭くなり，粒子の重なりも無 くなるが，線上に粒子の欠損がみられるようになる。 
すなわち，連続的な線とならない。

直線状に配列した粒子の光学顕微鏡像をデジタル画 像化し, 画像解析ソフトを使い, 粒子の付着位置分布 を調べた。その結果, 線に平行な方向には均一分布, 垂直な方向には正規分布していることがわかった。均 一分布のパラメータである粒子数の線密度は粒子像の 強度, 正規分布のパラメータである標準偏差は粒子像 の鮮明度に，それぞれ対応するものと考えられる。従 って, 線密度が高いほど, また標準偏差が小さいほど 良い配列像であるといえる。

配列条件と, 粒子数の線密度および標準偏差の関係 を定量的に調べたが, 全体としては粒子数の線密度が 大きくなると標準偏差も大きくなっていくことがわか る。

粒子への帯電や, 分散液の供給方法の改善等で, 線 密度を大きくして標準偏差を小さくすることは可能で あろうが，それでも本方法では粒子位置のばらつきは ある程度は避け難いと思われる。粒子を構成要素とし て材料を作るという観点からは, 粒子の位置制御が多 少悪くなっても, 複数種類の粒子を配置できる方が重 要である。

配列操作の際に, 溶媒中で粒子が帯電パターン上に 吸着する様子を光学顕微鏡で観察すると, 粒子は溶媒 の流れに乗ってランダムに移動しており, 粒子が帯電 パターンから $20 \mu \mathrm{m}$ 程度の距離に近づいたときに, 急 に進路や速度が変わり, 帯電パターンに引き奇せられ て付着する。一方ノイズ粒子の場合は, 粒子の速度が ゆっくりと遅くなり, 軟着陸するように基板の上に付 着する。

基板上の電荷は静電場を形成し，近傍の物体にさま ざまな力を及ぼす。その中で粒子を引き寄せる可能性 があるのは, グラディエントカおよびクーロン力であ る。グラディエントカは不均一電場中の物体が分極し て, 電気力線が集中する方向に引き寄せられる力で, クーロン力は帯電した物体が逆極性の電荷に引き寄せ られる力である。溶媒中の粒子に電荷を付与すること はしていないが, 液との摩擦により帯電していること は充分に考えられる。一方の力のみが粒子に作用して いるとして，簡単なモデルからそれぞれの力の大きさ を概算したが, どちらの場合も観察結果とは一致しな かった。現在のところは，いずれの力が主として作用 しているかは不明である。

\section{2.3 固定および積層 ${ }^{19)}$}

基板上に配列した粒子は, 静電気力のみでなくファ ンデルワールスカでも付着している。付着力は, 電荷
が消失した後でも, 通常の取扱では動かない程度に強 い。しかし, 電子ビームやイオンビームが付着粒子の 近傍を走査すると, 粒子がビームに引きずられるよう に移動することが観察されている。

例えば複数の種類の粒子を配列して, 基板に粒子膜 を作るといった場合, 2 回目の描画は, 最初に配列し た粒子に隣接して行われる。従って, 最初に配列した 粒子を固定してから描画を行わなければ，描画中に配 列粒子が動く。

固定に際しては, 配列している粒子が移動しないこ と, 繰り返して行う描画や配列に影響しないこととい った条件が課せられる。固定する方法は, 熱処理や機 械的プレス, 被膜の形成といったことが考えられ，そ れぞれ粒子の種類や特性に応じて選択することにな る。モデル粒子として $\mathrm{SiO}_{2}$ を用いた実験では, 被膜 形成による固定および熱処理による固定の 2 通りを行 った。

前者は，粒子を配列した基板に市販のコーティング 液を塗布し, 熱処理を加えて, フッ素系被膜を形成す る方法である。被膜のある基板に繰り返して描画, 配 列を行ったが, 配列している粒子の移動や剥離はな く，また描画プロセスや配列プロセスに対する影響も 認められなかった。一方後者の方法では, 大気中で $1150{ }^{\circ} \mathrm{C} ; 30$ 分の熱処理により, 固定できることを確 認した。

帯電領域は深さ方向にも数十 $\mu \mathrm{m}$ 程度広がるので, 例えば厚さ数 $\mu \mathrm{m}$ 単粒子膜の上に粒子配列ができた としても, 単粒子膜の下の基板が影響していると考え られる。そこで粒子配列を基板とは無関係に何回でも 繰り返せることを実証するために, 厚さ約 $200 \mu \mathrm{m} の$ $\mathrm{SiO}_{2}$ 粒子積層膜を作り，その上にこれまで述べてき た方法で粒子配列を行った。その際には, 配列した粒 子を積層膜の粒子と区別するために黒色の $\mathrm{SiO}_{2}$ 粒子 を用いた。積層膜が平滑でないために, 配列粒子像は 鮮明ではなかったが, ほぼ指定の位置に粒子が付着す ることが確認された。従って，原理的には描画，配 列, 固定を繰り返すことにより, 立体的な粒子配列構 造体ができることがわかった。

ただし，実際に 3 次元構造体を作り，材料やデバイ スとするためには，ノイズ粒子の除去や粒子付着位置 の精度をもっと高くするとともに, $\mathrm{SiO}_{2}$ 以外の粒子 の配列条件を調べる, 等の検討が今後必要である。

\section{3 粒子配列技術の応用}

ビームを利用した粒子配列技術を用いれば，複数種 類の粒子を基板上の任意の位置に配列できる。粒子の 
(a)

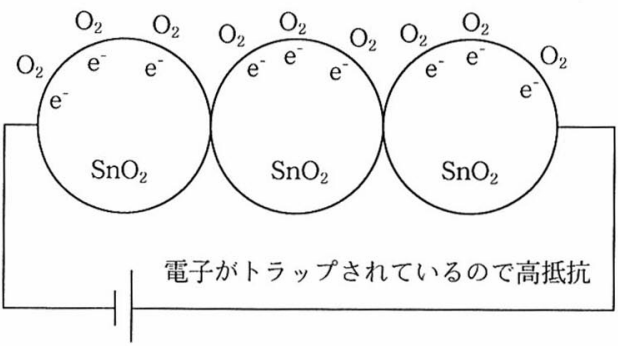

(b)
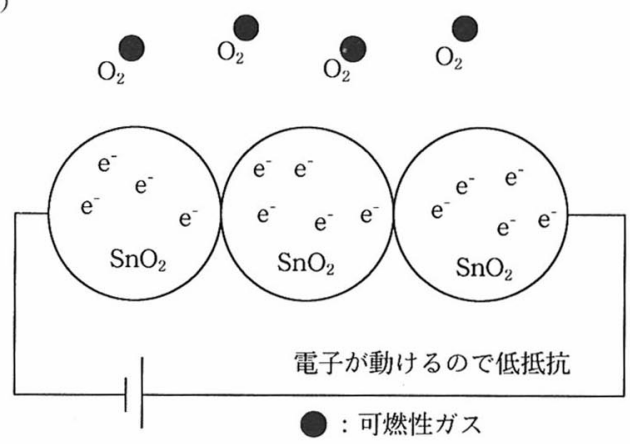

図 12 ガスセンサーの原理図

(a) 可燃性ガスがない状態,

(b) 可燃性ガスがある状態

大きさは結晶粒に匹敵する大きさであるので，立体的 な積層が実現できれば，結晶粒径の揃った材料や，規 則的に第 2 相が分散した材料を設計し, 設計図通りに 作製することができるようになる。現在のところは積 層が可能であるとの見通しが得られた段階である。そ こで 2 次元的な配列でできるガスセンサーおよび光学 デバイスへの応用を検討した。

代表的な可燃性ガスセンサーの原理図を図 12 に示 す。ガスの検知は $\mathrm{SnO}_{2}$ のような $\mathrm{n}$ 型半導体粒子同士 の接触面で行われる。すなわち, 可燃性ガスの存在の 有無により, 粒子の表面の酸素の吸着状態が変化し, それによる粒子間の電気抵抗の変化からガス濃度を検 出し得る ${ }^{20)}$ 。

市販のセンサーでは, このガス受感部は粒子焼結体 であるが，これは線状に配列した粒子で置き換えられ る。粒子が連続的に並べば, 線幅に多少のむらがあっ ても受感部としての機能を果たすが, 図11からわか るように, 現在の開発段階で充分に実現できるだろ う。粒子配列により受感部を作製すると, 小型化が可 能となり感度が増すことが期待される。また, 複数種 類の粒子を並べることが可能な本法の特長を活かし て, ガス吸着特性が異なる粒子を平行に並べると, 同 時に複数のガスを測定できるマルチセンサーとなる。

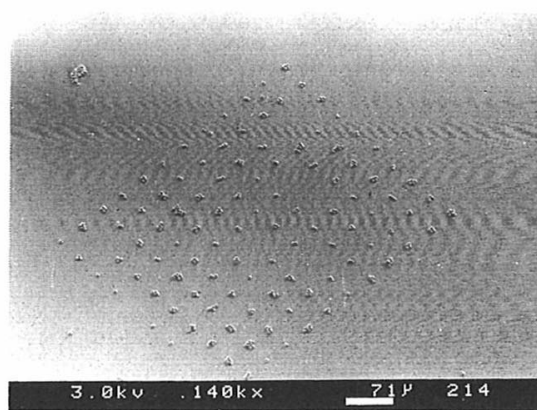

図13スポット帯電上に配列した粒子

このようなセンサーは現在検討段階であるが，充分に 実現可能である。また同様に，粒子の吸着特性を利用 したイオンセンサーや湿度センサーへの応用も可能と 思われる。

ミクロン〜サブミクロンの粒子で, 非常に精密な粒 子の周期的な構造を作ることができれば, 光フィル ター, 光スイッチ等の光学的なデバイスとなる ${ }^{211}$ 。こ のような光学的応用の可能性を探るために, 基板上の 格子点の位置にスポットの帯電像を作り, 粒子を 1 つずつ格子点位置に配置することを試みた。結果を 図13に示す。ほぼ描画スポットに対応した位置に粒 子が付着したが, わずかではあるが粒子の欠損があ り, また 1 つのスポットに 1 個以上の粒子が存在する 場合がある。プロセスの工夫により帯電パターンの広 がりを抑えることを検討しているが，もし帯電スポッ 卜の広がりを $1 \mu \mathrm{m}$ 程度に抑えることができれば, 各 スポットに粒子を 1 つずつ配置することが可能とな り，上記のような光学的応用が開けると思われる。

\section{4. 粒子アセンブルの展望}

機械部品や電子部品を代替するような高度な機能を 発現する材料は, 電子機器やメカトロニクスといった 分野での応用が期待される。そのような材料の創製を 可能にするプロセス技術として, 粒子アセンブルの概 念を提唱し22)，粒子アセンブルを実現するための具 体的な技術として，ここではオーダードミクスチャー 作製技術及びビームを利用した粒子の集積技術につい て述べた。

図 14 は, 粒子アセンブルでキーとなる粒子の位置 制御技術についてまとめた図である。位置制御にはさ まざまな方法があるが，I 粒子を 1 つずつ操作する, II 粒子群として操作する， III 自己組織化を利用する, の3つに分類した。 


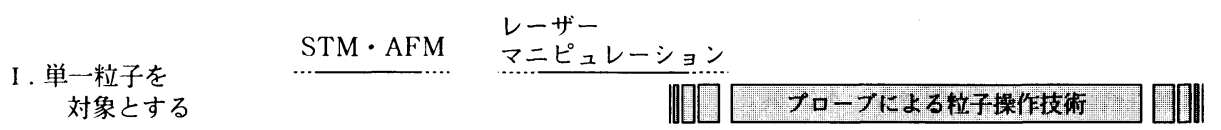

II . 粒子群を対象とする $\quad \begin{aligned} & \text { クラスター } \\ & \text { イオンビーム }\end{aligned}$

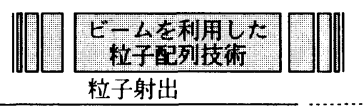

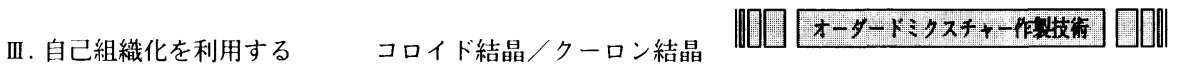

\begin{tabular}{|c|c|c|c|c|c|}
\hline \multirow{2}{*}{$\begin{array}{l}\text { 粒子 } \\
\text { サイズ }\end{array}$} & \multicolumn{5}{|c|}{ クラスター 】 超微粒子 } \\
\hline & \multicolumn{2}{|l|}{$1 \mathrm{~nm}$} & \multicolumn{2}{|l|}{$1 \mu \mathrm{m}$} & $1 \mathrm{~mm}$ \\
\hline & $10^{-9}$ & $10^{-8}$ & $10^{-7}$ & $10^{-5}$ & $10^{-3}$ \\
\hline
\end{tabular}

図 14 粒子の位置制御技術

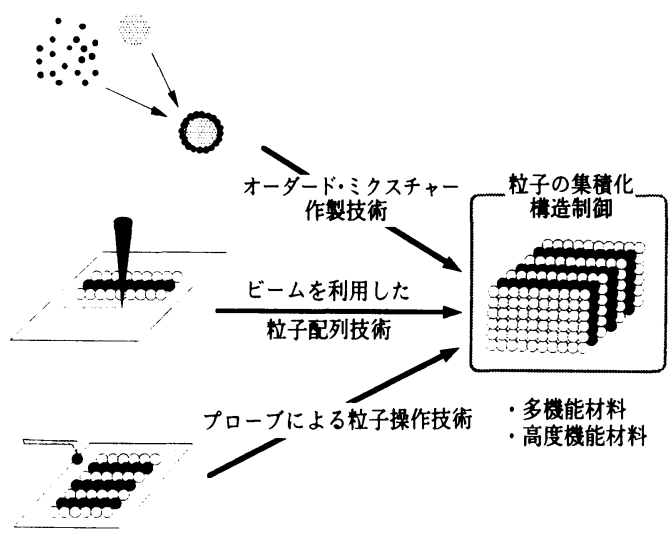

図15＼cjkstart粒子アセンブルによる，デバイスの作製の概念図

ここで述べたオーダードミクスチャー作製技術は III，ビームを利用した粒子配列技術は II に分類される であろう。ここでは述べなかったが，われわれの研究 グループでは I に分類されるプローブ（探針）による 粒子の操作技術の研究も行っており，粒子の位置を決 めての接合を行(23), アクチュエーターを試作して
(る ${ }^{24)}$ 。現在は，それぞれの個別技術を高めて応用を 目指す研究を行っているが, 最終的な目標は粒子アセ ンブルであり，図15に示すように，それぞれの技術 を結合して，粒子からセンサーやアクチュエーター等 の複数の機能を集積した新しい材料やデバイスを作る ことである。

図 14 の位置制御を含め, 粒子の操作技術研究の現 状を概観してみると, 研究対象はナノ粒子に集中して いるといえる。これは観察技術の進展が急速ですでに 原子レベルまでの観察が可能になっているのに対応 し，ナノ粒子が新たに操作可能な対象となったのが大 きな誘因と思われる。しかしサブミクロン以上の粒子 に対する操作技術の高精度化といった研究は少なく， むしろわれわれが必要とする粒子アセンブル技術は未 踏領域となっている。

今後，集積化，高機能化を軸にした新材料創製のた めには, 粒子アセンブルのような技術が要求されるよ うになるであろう。その際, われわれが研究している ような方法は, 粒子から材料へ至る 1 つの道と考えて いる。

\section{References}

1）新谷紀雄 : “インテリジェント材料の研究開発動向”, 油圧 と空気圧, 24, 65-73 (1993)

2) 新谷紀雄: “インテリジェント（スマート）材料開発の背景 と展望”，素形材, 37, 16-21（1996）

3) 檀武弘, 江頭満, 京野純郎, 不動寺浩, 新谷紀雄: “強制帯 電処理による半導体化 $\mathrm{BaTiO}_{3}$ - In 複合粒子の作製とその PTC 特性”, 粉体工学会誌, 33，848-854，（1996）

4) 檀武弘, 江頭満, 京野純郎, 不動寺浩, 新谷紀雄: “V型電
気抵抗温度特性をもつ複合粒子の作製”，1996 年度粉体工 学会秋期研究発表会講演論文集, pp. 141-143, 東京 (1996)

5) 小林幹彦, 不動寺浩, 長谷正司, 新谷紀雄: “電子・イオン ビームによる粒子アセンブル”，固体物理, 32, 755-761 (1997)

6) 新谷紀雄, 江頭満, 京野純郎, 岸本哲: “帯電処理による複 合粒子を利用した材料製造法”, 特許第 2005311 号, 
1996. 1. 11

7) 檀武弘, 江頭満, 京野純郎, 不動寺浩, 新谷紀雄: “帯電処 理による温度特性機能複合粒子の製造法”，特許第 2694895 号, 1997. 9. 12

8) 小石眞純：“微粒子設計”, p. 155, 工業調査会 (1987)

9) 静電気学会編 : “静電気ハンドブック”, p. 99, オーム社 (1992)

10) Dan T., M. Egashira, J. Kyono, H. Fudouzi and N. Shinya: "Preparation of new PTCR material by particle electrification processing", Proc. 5th Symp. on Intelligent Materials \& UK-Japan Seminar on Intelligent Materials, 47-49 (1996)

11) Shinya N., T. Dan, M. Egashira, J. Kyono, and H. Fudouzi : "Preparation of new PTCR material by particle electrification processing", Proc. SPIE Smart Structures and Materials 1997 (Smart Materials Technology), pp. 41-50, San Diego (1997)

12）檀武弘, 江頭満, 京野純郎, 不動寺浩, 新谷紀雄: “強制 帯電処理複合粒子によるV型電気抵抗温度特性材料の試 作”, 第 6 回インテリジェント材料シンポジウム講演概要集, pp. 34-36 , 東京 (1997)

13）檀武弘, 江頭満, 京野純郎, 不動寺浩, 新谷紀雄: “ $V$ 型 電気抵抗温度特性材料”, 特願平 8-313884, 1996. 11. 25

14）新谷紀雄, 岸本哲, 江頭満, 京野純郎: “部品の製造法”, 特許第 2600097 号, 1997. 1. 29

15）不動寺浩, 汇頭満, 新谷紀雄 : “電子ビームを用いたセラ ミックス基板上への帯電像の形成とその観察”, 日本セラミ ックス協会学術論文誌, 104, 556-561 (1996)

16）不動寺浩, 江頭満, 新谷紀雄: “集束イオンビームによる セラミックス基板上への帯電の形成”, 日本セラミックス協
会学術論文誌, 105, 611-615（1997）

17）小林幹彦, 不動寺浩, 江頭満, 新谷紀雄: “ $\mathrm{CaTiO}_{3}$ 基板上 への $\mathrm{SiO}_{2}$ 粒子の配列プロセス”，資源と素材，112, 481-486 (1996)

18) Kobayashi M., H. Fudouzi M. Egashira and N. Shinya: "Particles arrangement on dielectric substrates using electron beam", Proc. Int. Symp. on Microsystems Intelligent Materials and Robot, pp. 205-208, Sendai (1995)

19) 小林幹彦, 不動寺浩, 江頭満, 新谷紀雄: “配列粒子の被 膜形成による基板上への固定”，資源と素材，114，（1998） No. 2 に掲載予定

20）清山哲郎：“化学センサー”, 共立出版（1985）

21) Joannopoulos, J. D., R. D. Meade and J. N. Winn : "Photonic Crystals", Princeton Univ. Press (1995)

22) Shinya, N., M. Egashira and H. Fudouzi : "Powder particles assembly using electron beam for creation of multi-functional materials", Proc. of 2nd Int. Conf. on Intelligent Materials, pp. 1142-1151, Williamsberg (1994)

23) Konno T., M. Egashira and N. Shinya: "Powder particle manipulation using micro-probe and assemblage of micro-structure", Proc. Int. Symp. on Microsystems Intelligent Materials and Robot, pp. 447-450, Sendai (1995)

24) Shinya, N., T. Konno and M. Egashira : "Micro-scale structure fabrication using micro-probe", Proc. SPIE Smart Structures and Materials 1996 (Smart Electronics and MEMS), pp. 36-44, San Diego (1996) 